\title{
Urbanization, Culture and the
}

\section{Dutch Origins of the European}

\section{Enlightenment}

WIJNAND W. MIJNHARDT | UTRECHT UNIVERSITY

The Dutch Republic currently plays a prominent role in the big debates on the origins and nature of the European Enlightenment. However, relatively little attention has been devoted to the role played by urbanization in this. This contribution focuses on the specific form of urbanization that took place in Holland, and a compelling relationship is established between urbanization in the coastal provinces and a series of political and religious issues that were of decisive importance in the early European Enlightenment. The high watermark of this Dutch contribution can be found in the period 1680-1730. After this, and closely related to the decrease in urbanization and the social problems associated with economic decline, the Dutch Enlightenment would acquire a character all of its own, unfamiliar to other Europeans.

Until the end of the 1960s, the historiography of the Enlightenment was a rather clear-cut affair. Intellectual historians were in agreement on a range of issues. The Enlightenment had Paris as its centre, and the rest of Europe as its periphery; it had its intellectual heroes and its humble disseminators, and most importantly - the Enlightenment was considered first and foremost as a course in philosophy and ideas. In short: the Enlightenment was primarily an intellectual phenomenon and it was from France that the light shone forth, illuminating the rest of Europe.

Over the last few decades, under the influence of a great number of social historians, this French, intellectual vision of the Enlightenment has been replaced by a social interpretation. The Enlightenment has become chiefly associated with the efforts of local literati to identify problems and to contribute to their solutions. ${ }^{1}$ Nevertheless, this social approach emphasizing eighteenth-century practices instead of philosophy - has also found a growing number of critics, deploring the fragmented character and the lack of intellectual cohesion of the new vision. However, an unqualified 
return to the interpretation of the Enlightenment as a unified, philosophical phenomenon advocated by some historians is hardly convincing, on many counts.

Most importantly, the philosophically inspired Enlightenment syntheses - whether Peter Gay's The Enlightenment: An Interpretation of the 1960s, Franco Venturi's Settecente Riformatore of the 1970s and early 198 os, or most recently Jonathan Israel's Spinozist reinterpretation of the Enlightenment - all suffer from what Quentin Skinner has dubbed the 'fallacy of essentialism'. As Peter Reill stated in a recent lecture, this fallacy leads us to first conceive of the Enlightenment as a philosophical unity, then secondly to the conviction that the Enlightenment must be equated with modernity and that all achievements and ills of the modern age can be associated with the Enlightenment. Little wonder then that all writers of philosophically inspired syntheses have conceptualized the Enlightenment as the will to transform the world through ideas and politics. ${ }^{2}$ Any viable new approach to the Enlightenment must first confront these defects and then, just as importantly, incorporate the impressive advances made in social history.

These rival models of interpretation - the philosophical and the social - nevertheless have one common characteristic. They both result from the still widely accepted practice of writing national histories. Even though the eighteenth-century Enlightenment had an outspoken cosmopolitan and international dimension, research into the movement until today has continued to be chiefly motivated by national needs, images and traditions. As a result, we are confronted with a historiography of the Enlightenment that is seriously myopic, as vividly exemplified by Gertrude Himmelfarb's recent contribution to the debate, entitled: The Roads to Modernity: The British, French and American Enlightenments, conceived to supply a respectable history to the neoconservative concept of a fundamental divide between the old continental Europe that clings to the past and an Anglo-American condominium that presides over the future. ${ }^{3}$

I would like to thank Hugh Dunthorne, Ernestine van der Wall and Klaas van Berkel for their helpful comments on an earlier version of this article.

Roy Porter and Mikuláš Teich, The Enlightenment in National Context (Cambridge 1981) can be interpreted as the canonization of this social approach, Marie Christine Skuncke's volume: Centre(s) et périphérie(s): Les Lumières de Belfast à Beijing (Paris 2003) is a recent survey. Cf. Mikuláš
Teich, 'How It All Began: From the Enlightenment in National Context to Revolution in History', History of Science 41 (2003) 335-342.

2 Peter Reill, Rethinking the Enlightenment: Nature and Culture in the High and Late Enlightenment (Burgerhartlezing, Werkgroep Achttiende Eeuw; Amsterdam 2008).

3 Gertrude Himmelfarb, The Roads to Modernity: The British, French and American Enlightenments (New York 2004). 
On top of this, since the early 1980 , a small group of historians from the US, the Netherlands and England has presented a radically new geography, as well as a radically new timetable, for the Enlightenment ${ }^{4}$, shifting its origins from eighteenth-century France to revolutionary England of the mid seventeenth-century and even to the Dutch Republic. With a certain amount of rhetorical exaggeration, we might even say that present-day Enlightenment studies are at a dead end owing to the confusion concerning the most appropriate methods and approaches; the problems about where to locate the centre, and finally the uncertainty concerning the timetable, all of which are aggravated by the national reflex.

One possible way out of this deadlock - and one I would like to open up for discussion here - is an understanding of the Enlightenment as a social as well as a philosophical phenomenon, whereby geographical differentiation is still necessary, but not necessarily along the lines of national territories. Mightn't it be useful to look at the European Enlightenment anew, but this time with economic development, division of labour, social mobility, political organization and religious persuasions as fundamental preconditions? Mightn't factors such as these not be chiefly responsible for the origins and easy dissemination of Enlightenment thought? If we take such preconditions to be of decisive importance, then parts of England, the northern Hanseatic city republics and especially the western seaboard provinces of the Dutch Republic stand out because of their Protestant, mercantile and especially urban character.

Let us develop the urban argument for a moment and take a look at the well-known figures for European urbanization in the early modern period: ${ }^{5}$

European urbanization rates in a comparative perspective (cities >2500)

$\begin{array}{rrrrr} & \text { Europe } & \text { Dutch Republic } & \text { Holland } & \text { Other Provinces } \\ 1525 & 9 \% & 27 \% & 44 \% & 22 \% \\ 1675 & 10 \% & 42 \% & 61 \% & 27 \% \\ 1750 & 10,5 \% & 39 \% & 61 \% & 25 \% \\ 1795 & 11 \% & 37 \% & 60 \% & 24 \% \\ 1815 & 12 \% & 35 \% & 57 \% & 23 \%\end{array}$

4 Cf. Margaret Jacob, Radical Enlightenment: Pantheists, Freemasons, and Republicans (London 1981), the many publications of Theo Verbeek on Descartes and those of W. Klever on Spinoza and his circle, Wiep van Bunge, From Stevin to Spinoza: An Essay on Philosophy in the Seventeenth-Century Dutch Republic (Leiden 2001) and Jonathan Israel,
Radical Enlightenment: Philosophy and the Making of Modernity (Oxford 2001).

5 Jan de Vries and Ad van der Woude, The First Modern Economy: Success, Failure and Perseverance of the Dutch Economy, 1500-1815 (Cambridge 1997) 57-71. 
Number of cities and estimated population in the Dutch Republic 1500-1800

$\begin{array}{rrrrr} & \text { Holland } & \text { Other Provinces } & \text { Dutch Republic } & \text { Total Population } \\ 1525 & 17 & 21 & 38 & 1,250,000 \\ 1675 & 23 & 38 & 61 & 1,900,000 \\ 1750 & 21 & 39 & 60 & 1,950,000 \\ 1795 & 19 & 42 & 61 & 2,000,000 \\ 1815 & 20 & 43 & 63 & 2,100,000\end{array}$

We need not concern ourselves here with details, but a few conclusions stand out. The Dutch Republic, and especially its western seaboard, shows an exceptionally high level of urbanization; a stage that even industrialized England and Wales would only reach in the nineteenth century. In the western part of the Republic, cities were rarely very large. Amsterdam, with its 200,000 inhabitants, being the notable exception. However, urban centres were widespread. Wherever you resided, there were always cities on the horizon.

On the western seaboard, by the later sixteenth century the countryside had already lost its crucial role in the food supply, and therewith the economic and political significance it would it retain in all other European states until far into the nineteenth century. On the western seaboard, the aristocracy had lost its primordial political and social functions to citizens, who had taken over these roles. For instance, no fewer than fifty-seven Dutch cities were directly involved with the national decision-making process through the assemblies of the Provincial Estates.

At the end of the seventeenth century, this period of extraordinary urbanization came to an end, and a serious process of de-urbanization set in. As this development was spread very unevenly, its dramatic effects are somewhat blurred by the statistics supplied here. Amsterdam, for instance, only began to lose inhabitants after 1800 ; Rotterdam showed sustained urban growth until the end of the twentieth century, but a great number of industrial and commercial cities such as Haarlem, Leiden, Delft, Zierikzee and Middelburg lost more than half their citizenry, often in less than two generations. Most seaboard cities now had to face scenes of poverty on a scale never before witnessed. To summarize: urban centres were of crucial importance to the Dutch Republic, and especially to the provinces of Holland and Zeeland: in the seventeenth century as a source of dazzling growth, in the eighteenth as a spectacle of brutal decline.

So much for the social. But also on the level of Dutch Enlightenment philosophy the seventeenth and eighteenth centuries present striking differences. Let us take a look for instance at the semantic development of the words verlicht and Verlichting, the Dutch equivalents of respectively 'Enlightenment' and 'enlightened' and especially the concepts behind it. The 
historical dictionaries present a rather clear cut set of meanings. ${ }^{6}$ In Dutch usage 'enlightened' had a double meaning since the early sixteenth century. On the one hand, 'enlightened' meant scholarly, enlightened by reason, free from prejudice. On the other, 'enlightened' could signify informed by the inner light, the light of the Holy Spirit. In the 166os these two separate, but interconnected meanings became each other's opposites and 'enlightened' was now paraded as a battle cry. In various Dutch treatises 'enlightened' came to signify informed by rational philosophy as opposed to 'enlightened' by the revealing, holy light, which in the view of their authors had led the world into darkness instead.

From the end of the seventeenth century on the common usage of the term 'enlightened' lost its radical and oppositional meaning. Especially in the second half of the eighteenth century in common discourse, in novels and philosophical treatises alike, the term almost exclusively came to mean: informed by reason, even to the extent of absorbing the initial, religious meaning of the adjective. Instead of opposites, as in the $166 \mathrm{os}$, the religious and secular meanings of the word had become one another's correlates. Furthermore, after the 1750s, 'Enlightenment' became a period term. It had become associated with civilization, harmony and progress, while at the same time acquiring a pedagogical value, becoming a guiding principle for private education and public reform. ${ }^{7}$

If we confront these social and intellectual findings, at least three questions present themselves. Firstly: is there a relationship between Dutch urbanization and the development of the character of the Dutch Enlightenment? In other words, did the problems related to spectacular urban growth on the western seaboard give rise to intellectual issues we now qualify as enlightened? Secondly, if such a meaningful relationship can be established, then - given the very early rise of enlightened debates in the Dutch Republic - should we consider the origins of the European Enlightenment as an essentially urban phenomenon? And finally, if all of this turns out to be plausible, we might have found at least one way out of the present impasse in the writing of Enlightenment history; one that is dependant on the integration of social and intellectual approaches.

I will argue that the social problems originating in rapid urban growth and religious and political destabilization in the seventeenth century, and those of economic decline and urban decay in the eighteenth, seriously influenced the emergence, development and character of the volumes, The Hague, Leiden 1864-2001).
7 Wijnand W. Mijnhardt, "The Construction of Silence: Religious and Political Radicalism in Dutch History', in: Wiep van Bunge (ed.), The Early Enlightenment in the Dutch Republic 1650-1750 (Leiden 2003). 
Dutch Enlightenment. It allowed seventeenth-century Dutch intellectuals to create a radical vocabulary with which to express social, religious and political problems, and to find solutions towards the tolerance, democracy and demolishing of all religious authority that mark the beginning of the European Enlightenment.

On the other hand, the dramatic consequences of urban decline in the eighteenth century stimulated Dutch literati to develop a radically new, collectivist approach to the Enlightenment issue of the pursuit of happiness. Characteristically, to these Dutch literati, the traditional 'multitudo' (the rabble) had become a relevant category, for the first time in Western History. Their analysis of the problems facing the declining Republic revealed that restoration and recovery were impossible unless the entire population had reached a certain cognitive and moral level of civilization: that it had in fact achieved citizen status. Citizenship therefore presupposed the right to education, work, poor relief and health care. In 1798, the first Dutch constitution indeed granted every inhabitant of the Republic these rights.

In this article, I will limit myself to the issue of the Dutch origins of the European Enlightenment. ${ }^{8}$ In order to be able to make this claim, at least two basic issues have to be dealt with. Firstly, the tenuous relationship between urbanization and culture, and secondly the even more complex connection between urban culture and enlightenment thought.

\section{Urbanization and culture}

Urban history may be a booming business today, but, unfortunately, very little attention has been paid to the question of why lasting intellectual and cultural achievements almost invariably emerge within the complex and interconnected geographies, economies and societies of cities. ${ }^{9}$ Economic historians have coined useful concepts such as the urban system assigning cities a place in a hierarchy of towns providing services as well as interpreting them as links between the regions and the outside world. Social historians have analyzed in great detail urban immigration and cultural historians

Dutch decline, perceived as well as real, and the character of the Dutch Enlightenment in the eighteenth century at length in Joost Kloek and Wijnand Mijnhardt, Dutch Culture in a European Perspective 2. 1800: Blueprints for a National Community (London 2005).
9 A rare exception is: Patrick O'Brien (ed.), Urban Achievement in Early Modern Europe: Golden Ages in Amsterdam, Antwerp and London (Cambridge 2001), especially O'Brien's introduction. Helpful is also Joel Mokyr, The Gifts of Athena: Historical Origins of the Knowledge Economy (Princeton 2002) and the extensive discussion on Mokyr's book in Tijdschrift voor Sociale Geschiedenis (2004) 110-132. 
have been doing invaluable work focusing on the emergence and typology of cultural infrastructures and their relationship to city size. None of them, however, has tried to explain why cities have been much more than simple sites of cultural and intellectual or artistic achievements, but rather a central source of these.

For this reason, I have found the work of the founding fathers of modern urban studies much more helpful. Especially the writings of the Chicago School of Robert Park, Louis Wirth and Robert Redfield in the first decades of the twentieth century, and Richard Sennett as their contemporary successor. ${ }^{10}$ The Chicago sociologists refused to accept the mechanical idea of a commercial market economy generating urban conditions. They were interested in the non-economic factors responsible for the culture of cities, for which they considered free choice and innovation to be essential. They opposed the ideas of the so-called German School of Max Weber, Georg Simmel and Oswald Spengler, that the city as such was condemning people to monotonous lives, as a result of having to deal with rational bureaucracies and personal contacts ruled by formal exchange instead of human feelings. In their view, creativity and free choice - almost paradoxically - were the result of behavioural impulses produced by the ecology of city life. To Park, Wirth and Redfield, people in the city invariably obtain a definite, even uniform character but also real freedom, just as their cities have identifiable structures and yet the capacity to change.

These insights help us to understand why Dutch cities did create an atmosphere conducive to change, innovation and flexibility. An absolutely crucial factor in my view was the breathtaking immigration statistics. In the seventeenth and early eighteenth centuries, more than 1.5 million people migrated to the western seaboard towns (of whom half a million were in transit). Only a third had their origins in the Dutch countryside. More than a million came from foreign countries. This made for an exceptional level of diversity: social, geographic, linguistic (inhabitants of Dutch cities were used to hearing a dozen or so different languages) and most of all religious: though many immigrants came from Calvinist territories, the majority were Lutherans and Catholics, as well as many Jews and a great variety of members of sects and other persecuted religions. This diversity, which came on top of the division of labour so characteristic of Dutch urban economics, produced a complicated system of entangled loyalties that made it extremely difficult to impose uniform standards of behaviour. As only violence could coerce nonconformists, the Dutch city functioned as a medium for free men to

(ed.), Classic Essays on the Culture of Cities (New York 1969) and Morris Janowitz (ed.), Burgess, Park and McKenzie on the City (Chicago 1967).
A helpful contribution to the problem of urban creativity is Margaret A. Boden, Dimensions of Creativity (Cambridge Mass. 1994). 


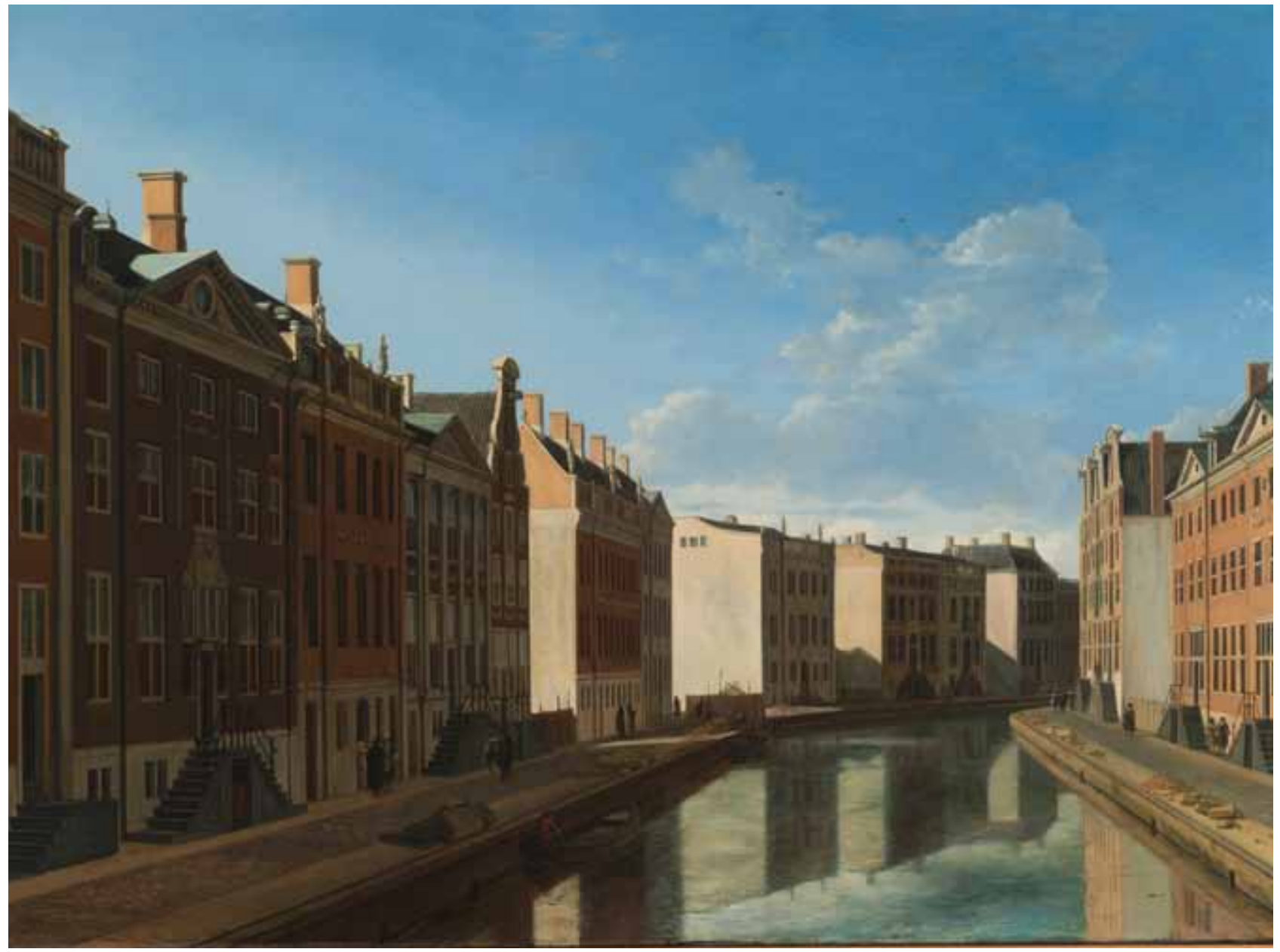

The richest part of the canal rings in Amsterdam, known for centuries as The Golden Bend.

Gerrit Adriaensz. Berckheyde, De bocht van de Herengracht, 1671-1672.

Rijksmuseum, Amsterdam. 
transcend general social values and to produce innovations that in the end were able to change urban society itself.

Nonconformity was aided by an essential brand of pedestrian cosmopolitanism. Dutch cities were the best places in Europe to obtain information of any nature whatsoever: political, religious, geographical, technical or scientific. No collector of fossils, shells, maps, books or charts could do without these merchant capitals of the world. And information was not confined to the dwellings of the elites. The great numbers of seafaring personnel of all ranks ensured an effective exchange, that reached deep into the social pyramid, of news and knowledge about the practices of far-off lands, and this stupefied traditional views, but also helped put them into perspective.

Urbanization Dutch-style also created a new kind of equality and individuality. Quite naturally, the Republic did have great hierarchical and social differences, but city life meant that this inequality could be, and at times was, lived and experienced in very different ways. In the towns, the various social classes lived in close proximity. The upper classes along the canals, the craftsmen on the long, intersecting roads, the shopkeepers and the unschooled on the cross-streets, while the poorest of the poor huddled in the abundant alleys and passageways every street and canal concealed. These (often underground) passageways and alleys connected a large number of cellar-dwellings and backyards crammed with yet another motley assembly of badly lit, ramshackle houses. This close physical proximity made social differences clearly perceptible, yet at the same time demanded they be bridged.

The result was an impressive self-regulating system of contact and social control, teaching the townspeople to give and take. Within this framework, conspicuous consumption was unacceptable and unwise. It is tempting to seek the origins of widely differing characteristics of Dutch early modern society, such as the inability to deal with social differences or its peculiarly tolerant practices, in precisely this system. Remarkably enough, this individualism is also reflected in the changing position of authors. Though patronage remained important, an ever-growing number of authors presented themselves to the public during this period, as they felt they had something to say to their fellow citizens in their own right.

Cultural creativity was also reinforced by the fact that Dutch urbanization had not resulted in the metropolis as an isolated island in an endless rolling countryside, but in an extensive urban network that was mutually dependant, competitive and unifying, all at the same time. Dutch towns had excellent connections not only with the outside world, but also with one another. Between 1600 and 1800 , the canal system performed the role of the motorway of modern times. Most Dutch towns could be reached comfortably and reliably within hours by towing barges, which passed several times a day and also by night. 


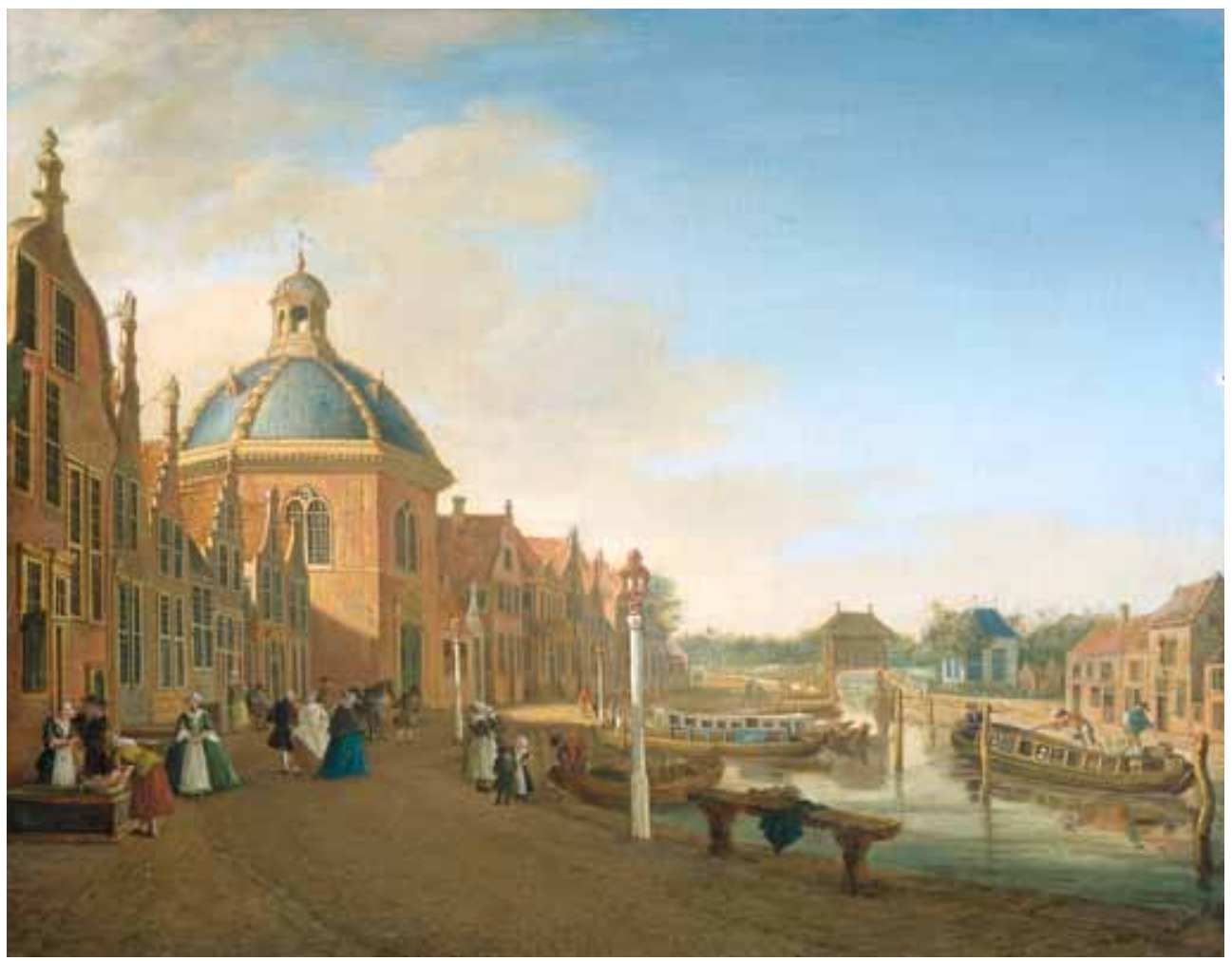

Paulus Constantijn la Fargue, View of Leidschendam with Towing Barges, 1756.

Rijksmuseum, Amsterdam. 
The cities were also united by language. In the Republic, the vernacular was in high esteem, even at the many universities. Though the great debate on the appropriate university language was lost by those in favour of the Dutch language, and Latin eventually became the scholar's tongue, the ideal remained unabated, in order not to isolate the Dutch world of learning. Many university publications were immediately translated into the vernacular. In the young Republic, which had to reinvent itself almost in every crisis - of which there were quite a few - these factors contributed to a lively and unique debate on almost all political, religious - and even scholarly and philosophical - issues.

Education was basic to city life. Personal Bible-reading was promoted from the pulpit, and city councils were convinced that practical skills such as writing and arithmetic were just as essential, resulting in a system subsidized by state and church aimed at making these ideals come true. Competition was not limited to commerce, industry and shipping. The small republic had a great number of universities and smaller colleges competing for students, as well as professors and, being dependant on state and city subventions, these were intent on making themselves useful. Though Amsterdam was the capital of publishing, bookshops were widespread in the Republic and competition created a network of information that included all cities.

All this resulted in an unrivalled 'public opinion', at least from a European perspective. The Republic was a very literate society, boasting large and mobile audiences that throve on large quantities of anonymous pamphlets covering internal and external politics and religious affairs, often accompanied by biting political commentary. The absolute icon of Dutch social, cultural and political integration was the Schuitpraatje, i.e. 'barge talk', the most popular variety of pamphlet culture. Barges were frequent, very reliable and democratic, but slow and therefore gave ample opportunity to discuss politics, philosophy and religion.

The ultimate proof of urban intellectual creativity was the emergence of a competitive value system. An interesting source for the new values were novels, and especially libertine novels. Their characters invariably are ordinary townspeople. They seldom cherish Christian moral concepts. The hard truths and pragmatic rules of city life prevail. They claim that human behaviour is determined by physical factors: money and economic relations determine the make-up of society at large. Therefore, social practice is not governed by moral philosophy. In their view, moral philosophy should be founded in social practice. Views that culminate in the vision of the happy whore who is socially acceptable, not for being virtuous (as in most foreign pornography), but for being what she really is: a human being selling a commodity. ${ }^{11}$ 


\section{The Dutch urban Enlightenment}

Even if a meaningful relationship between urbanization and cultural creativity can be established in Dutch early modern cities, it is clear that creativity and nonconformity in themselves do not produce an Enlightenment. Urban life can only construct a well-equipped theatre in which this can emerge. Central to the development of the ideas we call enlightened today, were the technological and social problems caused by brisk economic growth and rapid urbanization, and especially the seemingly endemic religious and political issues the young Dutch Republic had to cope with. Together, these set the intellectual agenda for local technicians, artisans and philosophers, professionals and laymen alike.

At the beginning of the Dutch Revolt, the revolutionary elites never planned to create an independent Dutch state, and never has there been a consensus on how to organize such a new state; nor was a viable solution available to the problem of the religious minorities. For this reason, the Republic was, despite its quick rise to European power, an extremely vulnerable state. Even the political system itself was questioned. To many revolutionaries, a Republic was inconceivable and, as a consequence, the sovereignty of the rebel provinces was offered to a series of European candidates. The only political document available was the Union of Utrecht, a treaty dating back to the first stages of the Revolt, which had never been intended to serve as the basis for a new state.

The central problems were those of sovereignty and political participation. ${ }^{12}$ Two pretenders to sovereignty prevailed: firstly, the provinces and the almost sovereign towns, that constituted the core of most Provincial Estates and saw themselves as the heirs to the Roman city state tradition. Secondly, the stadholders: the lieutenants of the Spanish king in the provinces, whom the revolution had left in place, and whose powers would increase in a centralized state. The main bone of contention was the States General. No one intended the States General, nor any of its organs, to be elevated to a sovereign position; yet both the stadholder and the province of Holland (which accounted for almost 60 percent of the state's financial burden) tried to extend the powers of the States General in order to enhance their own influence. As only temporary solutions were reached, sovereignty in the Dutch Republic was in permanent flux. 
No definitive solution for the issue of political participation was reached either. ${ }^{13}$ After the deposition of the king in 1581 , political power in the cities was often contested. Corporative local institutions, such as the guilds and the militias, claimed a role in local government, now that its power and authority had been greatly increased. Though most city councils managed to thwart formal corporative influence, they had, as a result, to accept a fundamentally unstable political structure that could only be balanced by seeking compromises acceptable to an ever-changing majority of local interests without pushing matters to an extreme.

The religious situation did not contribute to political stability either. ${ }^{14}$ The reason why religious diversity in the Dutch Republic was much more persistent than in England, France or Germany, owed much to the way in which the Reformation had been introduced into the Low Countries, and as a result none of the competing religions ever succeeded in gaining a strong majority: in the mid-seventeenth century, Calvinism and Catholicism were still at loggerheads, with some 40 percent of the population (or even less) each, while dissenters of an almost unimaginable variety, including those who had not yet decided to join one of the competing religions, constituted more than 20 percent of the population.

Religious diversity was also enhanced by the singular political structure of the Republic. The Dutch ruling classes would have very much preferred to be able to put pressure on the population to enter the Reformed church. Just like the English king or the German princes, they dreamed of a manageable, broad and popular established church that would supply a religious refuge for as many reformed groupings as possible. Two factors precluded the creation of such a broad and popular Reformed church: Orthodox Calvinists refused to accept less orthodox citizens into their churches, and consistories imposed strict rules of conduct on their flocks. The use of force in matters religious was equally impossible, as it would have violated the basic provision of the Union of Utrecht, the only semi-constitutional document the Dutch provinces had ever agreed upon, which stated (verbatim): 'that each person shall remain free in his religion and that no one shall be investigated or persecuted because of his religion'. A firm policy of Calvinisation was therefore out of the question. Moreover, Dutch city officials simply did not have the power, military or political, to enforce conformity, even if they had wished to do so. Consequently, religious

D.J. Roorda, Partij en Factie (Groningen 1961);

Henk van Nierop, 'Popular Participation in

Politics in the Dutch Republic', in: P. Blickle

(ed.), Resistance, Representation and Community

(Cambridge 1997) 272-290.
14 For a very useful analysis, Wiebe Bergsma, 'Church, State and People', in: Karel Davids and Jan Lucassen (eds.), A Miracle Mirrored: The Dutch Republic in European Perspective (Cambridge 1995) 196-228. 


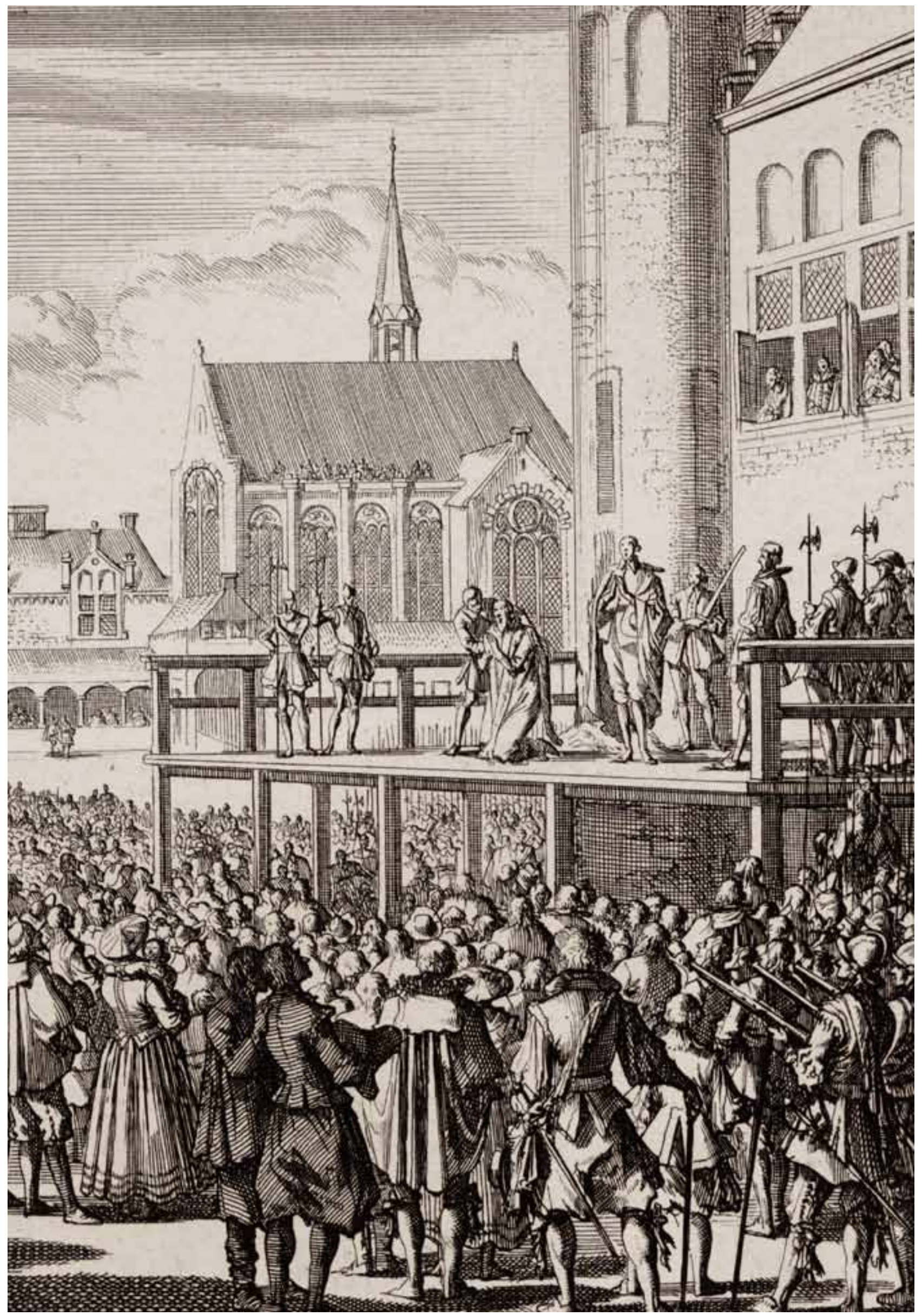


tolerance and freedom of the press were much greater than abroad. However, this freedom was not a modern personal right, and can only be understood within the unstable and complex political framework of the time, dependent as it was on ever-changing compromise. Religious disputes could very easily unite with political unrest amidst international crisis, as can be shown from the Arminian conflicts of 1617-1618, which led to the beheading of the chief state official, Johan van Oldenbarneveldt.

In the midst of endless social, religious and political strife, Dutch intellectuals developed an urban intellectual style that might be labelled as pragmatic empiricism. One of its early proponents was Simon Stevin (15481620), the famous mathematician and a pillar of Dutch scientific debate on the eve of the Scientific Revolution, and an important theoretician on civic life. His Vita Politica, het Burgherlick Leven (Leiden, Van Ravelingen, 1590) shows a departure from the classical and humanist tradition in its title alone. Stevin emphasized the necessity of empirical procedures based on social observation and historical examples. Though Stevin advised a resigned life, the citizen should not be afraid to act against unlawful government, if necessary. Stevin's plea to write intelligibly and about all topics in the vernacular would remain one of the central tenets of Dutch intellectual debate throughout the century. ${ }^{15}$

Hugo Grotius is another example of this empirical tradition, which preferred analysis of the actual political institutions of the Republic to more abstract political philosophy. Grotius' defence of tolerance is a case in point. It fell short of the more principled varieties on offer elsewhere in Europe, but took the actual Dutch issue of multiple religious creeds as its point of departure. Grotius claimed that only the basic tenets necessary for maintaining civil order (e.g., the existence of God and Divine Providence) ought to be enforced, while all other differences on theological doctrines should be left to private conscience; a position that, because of its realism, would eventually be adopted by most of the Dutch regents. ${ }^{16}$

Grotius' pragmatic empiricism also made him one of the founders of modern social thought. The Christian tradition assumed that human beings were incapable of living together peacefully. Only divine grace prevented the world from slipping into perpetual murder and mayhem, and therefore was the sole foundation of human society. Philosophers, however, began to wonder if one could conceive of a tolerably functional society without divine grace,

Jan Luyken, Johan van Oldenbarneveld Beheaded at

The Hague on 13 May 1619, 1698 (detail).

Amsterdams Historisch Museum.

\footnotetext{
Catherine Secretan (ed.), Simon Stevin: De la vie civile 1590 (Lyon 2005) and especially the contributions of Klaas van Berkel and Catherine Secretan.

16 For the relationship between Stevin and Grotius, see Richard Tuck, Philosophy and Government 1572-1651 (Cambridge 1993) 371.
} 


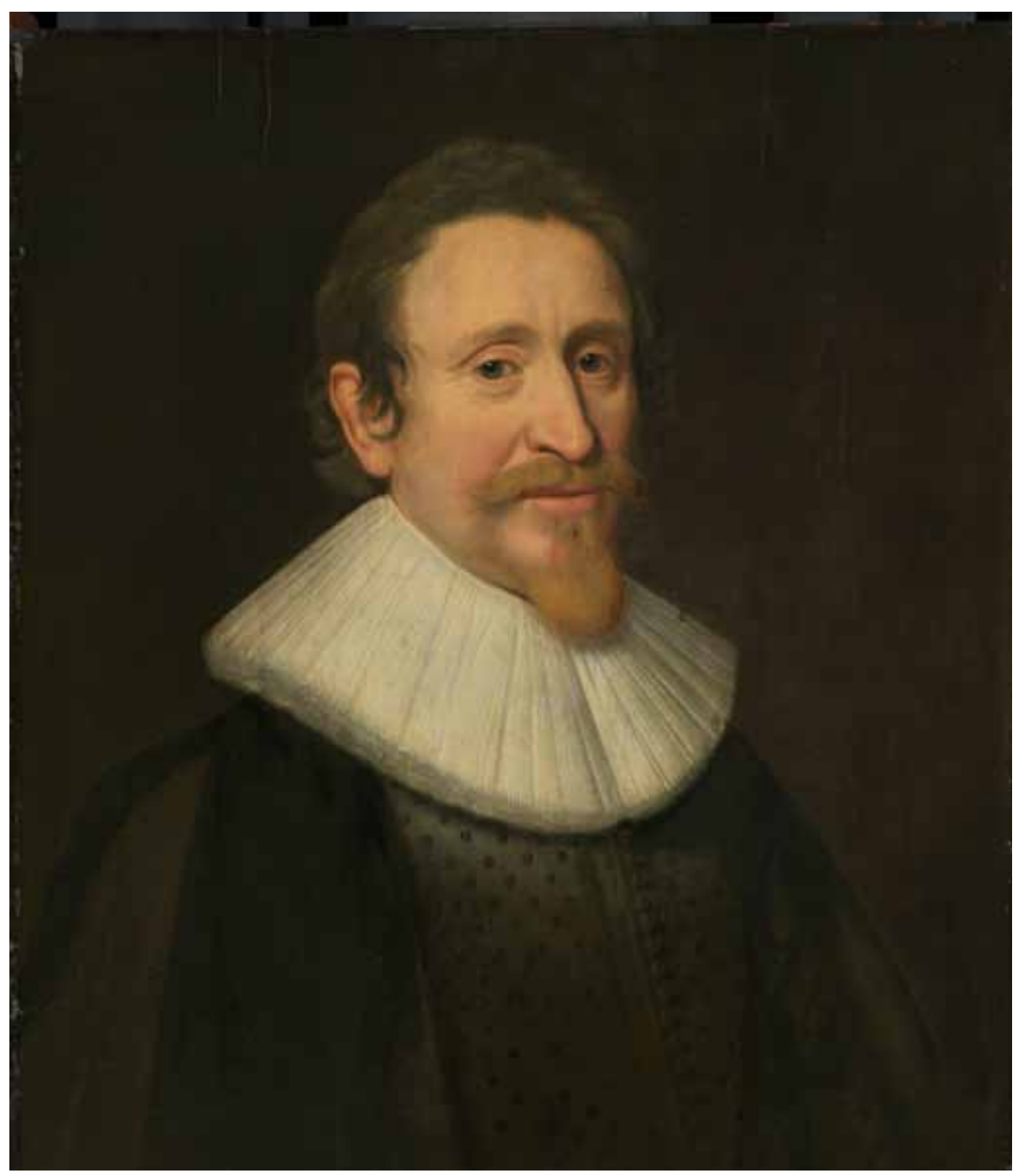

Michiel Jansz van Mierevelt, Hugo de Groot (1583-1645), 1631.

Rijksmuseum, Amsterdam. 
based on human endeavour alone. The question became ever more pressing as Europeans learned more about the world beyond their continent; about civilized societies that were not based on Christian dogmas and traditions.

Hugo Grotius became a prominent ideologue in this debate. He asked himself whether it was possible to formulate universal principles of law based on self-love - the only principle of human action left if God abandoned the world. Answering this question in the affirmative, he proceeded to devise a system of natural law (that is, one without any metaphysical foundations) based on the right of self-defence, from which logically derived an obligation, in his view, to avoid harming others. Grotius believed that this line of reasoning provided a legal basis for a human morality without any divine contribution. The consequences were immense. Grotius made it possible to conceive of a fully functional human society that sidestepped, as it were, the Christian dilemma. For rather than being faced with a stark choice between despair and divine grace, humans could achieve a liveable society in which life and property could be safeguarded. On the basis of these principles society as a human construct - could be analyzed, discussed and even improved. ${ }^{17}$

Stevin and Grotius were the most important among the early Dutch scientists who were prepared to argue issues without automatically taking recourse to ancient learning or ecclesiastical reasoning. They supplied a model of intellectual courage to an important group of followers, such as the mathematicians Frans van Schooten jr. and Jan Jansz. Stampioen and the mechanical philosopher Isaac Beeckman, a second-generation refugee from the Southern Netherlands, who would become the major source of inspiration to René Descartes. Without their audacity and their methods, the Dutch Enlightenment would have been difficult to imagine, and the merchant elite of the Dutch Republic very much valued their novel ways of knowing. ${ }^{18}$

Mid-century, the Dutch Republic was at its zenith but political, social, economic and religious issues still abounded. All these tensions were aggravated by the grand debate on the reconstitution of the Republic. The long and costly war against Spain had been ended at the Peace of Westphalia in 1648. The stadholder, a claimant to a political power, had died without a capable heir and the political fortune of the Orange family was low after a political revolution and an unsuccessful attack on Amsterdam. The relationship between the provinces was in need of a serious overhaul and

Baker, 'The Enlightenment and the Institution of Society', in: W. Melching and W. Velema (eds.), Main Trends in Cultural History: Ten Essays (Amsterdam 1994).

On the relationship between science and commerce, cf. Pamela H. Smith and Paula Findlen (eds.), Merchants and Marvels: Commerce, Science and Art in Early Modern Europe (New York 2002) and especially Harold Cook, Matters of Exchange: Commerce, Medicine, and Science in the Dutch Golden Age (New Haven 2007). For an extensive discussion of science in the Dutch Republic in the seventeenth century, see the contribution of Klaas van Berkel to this volume. 
all options seemed open again in relation to the future of the Republic. The ensuing vacuum fuelled imagination and creativity of all intellectuals, conformist as well as unorthodox, conservative as well as liberal. The orthodox Calvinists tried to solve the crisis by introducing the idea of a theocracy under the protection of a godly stadholder. The regents opted for an aristocratic republic, and did not recoil from a whiff of Hobbesianism in the process. The moderates most of all wished for a tolerant state.

Dutch radicals intervened in these fierce debates. Their tool was an idiosyncratic Cartesianism which had been taught freely at the universities since the 1640s, and had slowly been assimilated through the pamphlet system, even into street language, and which was soon reinforced as a philosophical instrument by an eclectic Spinozism. Both Spinoza and Descartes had developed their ideas in the Republic in close collaboration with, and heavily influenced by, Dutch literati. While Descartes himself had still entertained strict views on the number of subjects to which his ideas and methods could be applied, his Dutch colleagues went much further and employed Cartesianism to find solutions for all the problems that had been tormenting the young Republic since its inception: the nature of the political system, the relationship between church and state and the interpretation of the scriptures, which in the Republic had become a heavily politicized affair. ${ }^{19}$

Until the advent of Cartesianism, Dutch political theory (with a few exceptions) had essentially been academic, Aristotelian and humanist, with Calvinist constitutionalist overtones. At Leiden University, it was even monarchical. The influential propagator of this view, Leiden professor Franco Burgersdijck (1590-1635) in his Idea Politica (1635), praised monarchy as the original form of government, even though in his view the Republic would be best suited by a mixed constitution. ${ }^{20}$ It was the radical followers of Descartes outside the universities, such as the Utrecht magistrate Lambert van Velthuysen (1622-1683), Pieter de la Court (1618-1685), Franciscus van den Ende (1602-1677) and Spinoza (1632-1677), who tried to employ Cartesianism and Hobbesianism to solve the Republic's greatest political problems: to define and locate sovereignty, and to establish an acceptable degree of popular involvement in politics, taking human nature as their point of departure. ${ }^{21}$

The first Cartesian political theorist who addressed these problems was Velthuysen, who tried to steer a course away from Hobbesian absolute political philosophy. Since the Republic had its origin in war against tyranny, it could Spies, Dutch Culture in a European Perspective 1. 1650: Hard Won Unity (London 2005) 332-344.
H.A. Krop (eds.), Franco Burgersdyck (1590-1635) (Amsterdam 1993).

21 Hans W. Blom, Morality and Causality in Politics: The Rise of Naturalism in Dutch SeventeenthCentury Political Thought (Utrecht 1995). 
not possibly be tyrannical itself. Convinced that arguments from authority would have to cede to rational arguments, Velthuysen developed a new theory of sociability in which the rules and norms of public morality should be perceived as the results of the actual functioning of the social system. Pieter de la Court's True Interest should be interpreted as an attempt to propose a theory of republicanism on the basis of the new economic principles pervading the Republic. By defining common interest as commercial interest, he invented an economic version of the virtuous citizen. This enabled him to arrive at a theory of government subject to the commercial interests of its citizens. ${ }^{22}$ Van den Ende had a different diagnosis of the problems of the Republic, and a different solution too. For him, the future of the Republic was dependent on the introduction of full equality and full democracy in the Dutch towns. Only then could social mobility based on education and achievement be reconciled with political stability and civic concord in a rapidly expanding commercial society. Spinoza elevated their views to a coherent political philosophy. Though Spinoza never tried to offer an explanation of the actual Dutch republican system of politics, he proposed a radical democratic republic in which absolute sovereignty was the central safeguard against infractions on liberty and tolerance. Spinoza's synthesis met with heavy criticism, as his political state derived from a complete separation of theology (as a system of obedience) and philosophy (as a system of truth). ${ }^{23}$

The Dutch Cartesian debates on the exegesis of the scriptures are generally interpreted as another chapter in the history of religious scepticism that would end in full blown atheism. Though varieties of atheism might have occurred in Dutch intellectual circles, most radicals abhorred it, as can be illustrated for instance by Spinoza's complaint in one of his letters to Henri Oldenburg, the permanent secretary of the Royal Society. Spinoza writes that he plans to write a new treatise (the Tractatus Theologico-Politicus), if only to contradict the popular accusation of atheism. ${ }^{24}$

The dislike of atheism points to another explanation of the debates on the interpretation of the scriptures that better fits the singular religious and political structure of the Republic. What united moderate Calvinists, religious radicals and even most Spinozists, in my view, is their earnest endeavour to find a new basis for Christian concord. The Reformation definitely destroyed the unity of medieval Christendom, but most European states had succeeded

Very useful for the commercial impact on De la

Court's republicanism is Jan Hartman's Master's

thesis The Commercial Republicanism of Pieter de la

Court (Utrecht 2005).

23
Politieke Theorie in het zeventiende-eeuwse

Nederland (Amsterdam 1960); E.O.G. Haitsma
Mulier, The Myth of Venice and Dutch Republican

Thought in the Seventeenth Century (Assen 1980)

170-208.

24

Spinoza to Oldenbourg (September or October

1665) in: A. Rupert Hall and Marie Boas Hall

(eds.), The Correspondence of Henri Oldenburg,

volume 2 (Madison 1966) 542. 
in imposing new forms of religious conformity. Only in the Republic did religious strife continue to rage. As a result, from the late sixteenth century on, Dutch humanist scholars had been trying to end religious quarrels by invoking science and scholarship in order to create a new religious understanding capable of superseding dogmatic differences. This movement, to which Leiden professors such as Joseph Scaliger and Justus Lipsius adhered, also attracted laymen who founded loose associations, such as the Family of Love, that had similar objectives. The Familists dispersed in the early seventeenth century, but their ideology was passed on to the Arminians and to all those who tried to postpone as long as possible their decision to choose religious sides. ${ }^{25}$ The intellectual debates on religion and the interpretation of the scriptures inspired by Cartesianism should be seen as a renewed attempt to achieve an intellectual basis for religious unity or to devise new intellectual stratagems that would put an end to the permanent state of religious conflict. These ideas had a social basis in the many Chrétiens sans église that could be found in the Republic, and that convened in small groups - such as the Collegiants - or that were led by irenical Mennonites such as Galenus Abrahamsz (1622-1706), or more critical seekers like Johannes Bredenburg (1643-1691). ${ }^{26}$

As a consequence, we should be careful in interpreting radicals such as Lodewijk Meijer as erudite libertines Dutch-style, seeking to propagate atheism. Meijer was not a Grub Street writer, but a solid Amsterdam citizen and a central figure among those Dutch Cartesian intellectuals who were convinced that the libertas philosophandi would produce rational religious truths that could put an end to discord in Protestant Christendom. In the opening chapters of his Philosophia Sacrae Scripturae Interpres, clandestinely published in Eleutheropolis=Amsterdam in 1666 (a Dutch translation appeared one year later), Meijer argues that the present version of the Scriptures is so full of contradictions and discrepancies that it would be a disgrace to God to attribute its authorship to him. As a result, theology is in complete disarray. However, if Meijer's rational model of Bible interpretation

25 J.A. van Dorsten, The Radical Arts: First Decade of an Elizabethan Renaissance (Leiden 1970); idem, 'Tempora filia veritas. Wetenschap en religievrede', Tijdschrift voor Geschiedenis 89 (1976) 413-419; A. Hamilton, The Family of Love (Cambridge 1981).

Religieuse et le lien confessionel au XVIle siècle (Paris 1969); for some recent analyses: L. van Bunge, Johannes Bredenburg (1643-1691). Een Rotterdams Collegiant in de ban van Spinoza (Rotterdam 1990); Andrew Fix, Prophecy and Reason: The Dutch
Collegiants in the Early Enlightenment (Princeton 1991); M. Wielema, Ketters en Verlichters. De invloed van het spinozisme en wolfianisme op de Verlichting in gereformeerd Nederland (Amsterdam 1999); idem, The March of the Libertines: Spinozists and the Dutch Reformed Church (1660-1750)

(Hilversum 2004). Lodewijk Meijer, Philosophia Sacrae Scripturae Interpres, clandestinely published in Eleutheropolis=Amsterdam in 1666, preface. Cf. W. Klever, Mannen rond Spinoza (Hilversum 1997) 61-86. 
were to be generally adopted, theological conflicts - with their disastrous social and political consequences - would come to an end. ${ }^{27}$ Meijer was not the only one to entertain such hopes. Many contemporaries saw it as God's will that Christians should now reach agreement among themselves on a firm and unquestionable method for the exegesis of the Bible. ${ }^{28}$ For some, such as the Scottish theologian John Durie (who had many Dutch connections), such an interpretational unity was even a necessary precondition for the second coming of Christ. ${ }^{29}$

If we stress the quest for religious concord as a unifying element in the Dutch Cartesian debates, the intellectual efforts of major figures such as Balthazar Bekker also take on a new meaning. Bekker did not explicitly plan to liberate the world from belief in witchcraft, nor did he most of all want to free the world from superstition. Bekker experienced a life-long struggle with religious authority. Part of the persistent nature of this struggle should be explained - as modern research has stressed - by reference to Bekker's personal character. ${ }^{30}$ His polemics were dogged, and he was never prepared to accept compromise. However, central in his published writings from the Kort Bericht [Short Notice] of 1666 - in which he claimed the right to preach at his wife's grave - to his Friesche Godgeleerdheid [Frisian Theology] of 1693, is his crusade for exegetic liberty within the framework of the established Calvinist church. Bekker made free use of the accommodation theory so popular with his Cartesian colleagues. ${ }^{31}$ Bekker nevertheless differed in one fundamental aspect: he never questioned the meaning of the original Bible text, but only the later Dutch translation of it. ${ }^{32}$ Where Spinoza, for instance, ridiculed Bible passages and claimed that the authors of the Bible had made flagrant mistakes, Bekker never accepted the proposition that the Christ of the Bible was capable of erring. Bekker's reluctance to be associated with the radicals cannot be simply settled by reference to his fear of the authorities. On the contrary, Bekker almost always seemed to be on the lookout for new opportunities to clash with authority. tot Spinoza.

29 Scepticism in the Early Enlightenment', in: R.H. Popkin and Arjo Vanderjagt (eds.), Scepticism and Irreligion in the Seventeenth and Eighteenth Centuries (Leiden 1993) 212-241.

acob van Sluijs, Bekkeriana. Balthasar Bekker biografisch en bibliografisch (Leeuwarden 1994) 19-23.
31 Andrew Fix, 'Bekker and Spinoza', in: W.N.A. Klever and Wiep van Bunge (eds.), Disguised and Overt Spinozism around 1700 (Leiden 1996) 23-40. Cf. Andrew Fix, Fallen Angels: Balthasar Bekker, Spirit Belief and Confessionalism in the Seventeenth Century Dutch Republic (Dordrecht 1999).

32 Wiep van Bunge, 'Balthasar Bekker's Cartesian Hermeneutics and the Challenge of Spinozism', The British Journal for the History of Philosophy 1 (1993) 55-79. 
THE INTERNATIONAL RELEVANCE OF DUTCH HISTORY

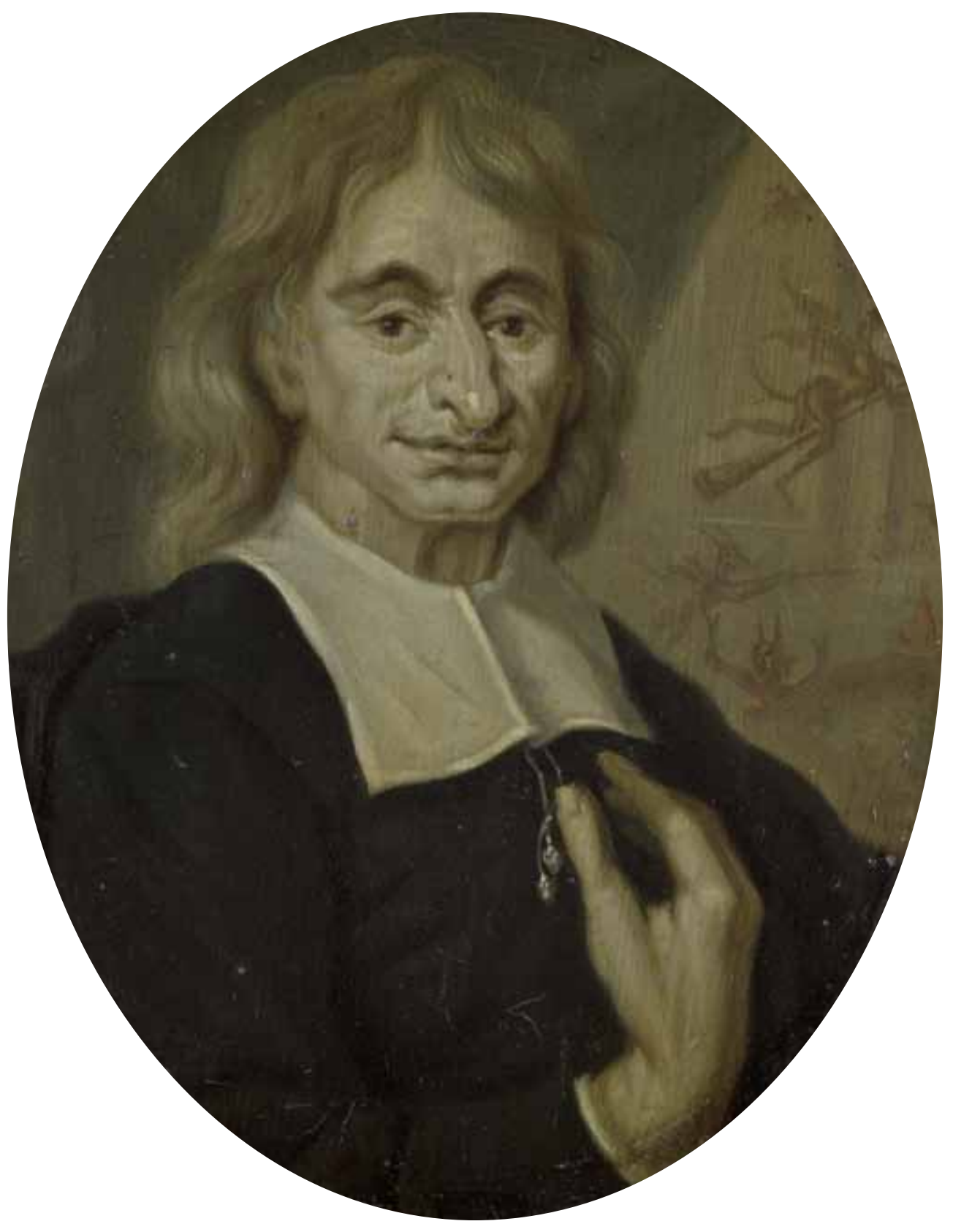


It was Bekker's aim to fundamentally broaden the religious basis of the established Calvinist church. By introducing a new, more moderate and inclusive method of biblical exegesis, he hoped to realize the aim of so many moderate Calvinists - regents as well as citizens - from the early seventeenth century on, namely the establishment of a liberal Calvinist church that would be capable of embracing the vast majority of Dutchmen. He thus hoped to achieve conformity by means of intellectual persuasion, rather than by force or violence. In this context, his refusal to be expelled from the church, or to leave it for the Remonstrant Society at his own initiative, as so many Calvinist ministers before him had done, seems only logical. The readiness of the Amsterdam magistrates to accept Bekker as a predikant in spite of his turbulent career and his many conflicts with church authorities, and their refusal to condone his expulsion from the church and their preparedness to continue to pay his salary until his death while leaving his post as minister vacant, should not be interpreted as another instance of inexplicable Dutch tolerance. As Bekker was one of the last great propagandists for the tolerant, broad middle church so many politique regents had been advocating since the 1590 , they saw him as a precious asset that should not be easily expended.

Cartesian influence did not limit itself to theology or political philosophy. It also played a decisive role in the constitution of science as a separate branch of knowledge. Dutch scientists made ample use of Descartes' philosophy, in which natural knowledge had been given its own legitimate place. However, to understand the hold of Cartesian natural philosophy on the mind of Dutch scientists, we should realize that they did not use this as ontology, but rather as an epistemology. Dutch scientists such as Christiaan Huygens (1629-1695) had discarded Cartesian metaphysics as early as in the second half of the seventeenth century, and conducted their research along strictly experimental lines. Practical experiments were even introduced in the universities, and the first theatrum physicum was established at Leiden University in 1675 . However, well-known Dutch researchers - for instance Huygens and Anthonie van Leeuwenhoek (1632-1723) - adhered strictly to the Cartesian separation of science from theology, even to the extent of hardly ever referring to God or scriptures in their published work. Despite their reticence on religious topics, the antagonisms between orthodoxy and the propagandists of the new science were manifold. An important bone of contention was the Copernican system, which the orthodox thinkers abhorred because it could not be reconciled with a literal interpretation of the Scripture. ${ }^{33}$

Arnoud van Halen, Balthasar Bekker (1634-1698). Minister and Man of Letters in Amsterdam, 17001732. Rijksmuseum, Amsterdam.
33

Rienk Vermij, The Calvinist Copernicans: The Reception of the New Astronomy in the Dutch Republic, 1575-1750 (Amsterdam 2003). 
From the 1670 os on, the radical Cartesians lost the initiative and began to meet with severe resistance. Some of their books were banned, their livelihoods were often imperiled and radicals, such as Adriaen Koerbagh, even ended their lives in prison. The moderate Calvinists from various persuasions tried to seize the initiative. Some were honest Cartesians. Others were followers of Johannes Cocceius (1603-1669), a very influential Leiden theology professor, who had won a large intellectual following composed of ministers and laymen alike, by contending that parts of Scripture should not be construed literally but interpreted figuratively and in terms of their historical context. ${ }^{34}$ All were equally intent on finding a solution to the ongoing religious battles. A crucial role in the framing of a new consensus in the field of theology and philosophy should be attributed to Herman Alexander Röell (1635-1718), professor of philosophy at Franeker University in Friesland, and Salomo van Til (1644-1713), professor in theology at Leiden University. 35 Röell and Van Til defended the divinity of Christ and argued against radicals of whatever persuasion. They exploited Cartesianism to the full and went further than any previous Cocceian theologian. They forged a theology linked to reason and produced a synthesis of the new philosophy and the Calvinist tradition, portraying Christianity as the most reasonable of all religions.

A similar service for science was provided by Bernard Nieuwentyt (1654-1718), a burgomaster and town physician from North Holland. Nieuwentyt no longer relied on the Cartesian framework in defence of science. He even gave his work an anti-Cartesian tenor by seeking an alliance with English experimental philosophy instead. The new attitude, however, did not entail any changes in the conduct of scientific research. Dutch physicists had already forged their own experimental tradition. The reasons for shifting away from Cartesianism were tactical in nature. Nieuwentyt wanted to make science acceptable, even within circles of orthodox believers who advocated a literal interpretation of the Bible. In his major book Het Regt Gebruik der Wereltbeschouwingen, Nieuwentyt argued therefore that modern science was totally in accordance with scripture, whereas the theories behind the materialist universe of the radical Cartesians and the Spinozist 'atheists' were untenable from a scientific point of view. ${ }^{36}$

As we have seen, Velthuysen and the De la Court brothers did not concern themselves with a full explanation of the constitution of the Dutch republic itself, while Spinoza's ideas mainly met severe resistance. The compromise in political theory was authored by the Frisian law professor

\footnotetext{
35 Jacob van Sluis, Herman Alexander Röell (Leeuwarden 1988).

36 Rienk Vermij, Secularisering en Natuurwetenschap in de zeventiende en achttiende eeuw. Bernard Nieuwentijt (Amsterdam 1991).
} 
Ulric Huber (1636-1694). Huber, a moderate Cartesian himself, succeeded in forging a political theory of republicanism which avoided the extremes of Hobbes and Spinoza, thus supplying the Cocceio-Cartesian compromise with a political basis. Huber tried to steer a clear course between the Calvinist constitutionalist tradition represented by the early seventeenth-century political philosopher Johannes Althusius (1556-1638) on the one hand, whose defence of absolute popular sovereignty in Huber's view would lead to chaos, and Hobbes' theories on the other, whose arbitrary sovereignty of some indifferent ruler would lead to slavery. Huber's ideal state consisted of a very broad constitutional aristocracy, with absolute sovereignty residing in as large a body of patricians as possible and with important civil rights explicitly reserved by the people. In his view the Dutch Republic came closest to this ideal. ${ }^{37}$

\section{Urban and European Enlightenment}

As early as the seventeenth century, contemporaries considered the Dutch Republic a very peculiar state: an upstart republic in a monarchical age, originating in mutiny and rebellion; and at the same time a safe haven of relative tolerance amid seemingly unending religious conflict. Compared to many other nations at the time, the Dutch seemed peaceful. Though not aggressive conquerors, they were strongly devoted to their independence and freedom. Of course, they were also envied for their wealth and power. After all, within a short time the Republic had reached an unsurpassed level of economic prosperity, political efficiency and cultural achievement. Though the later Middle Ages had already seen a remarkable urbanization, a high level of personal freedom and the emergence of an efficient market economy, by 1650 the Dutch had managed to become Europe's superpower, and would dominate world politics for the next half century. ${ }^{38}$

Moreover, inhabitants of other states had great difficulty understanding the nature of Dutch society. French aristocratic travellers complained that, in the Republic, everyone behaved as if they were equal, and a shrewd English diplomat like Sir William Temple was amazed at the fact that the Dutch had turned upside-down the orders by which a nation's strength could be measured in the seventeenth century: 'Small in territories at land [and] weak in number of native subjects, but mighty in riches and trade'.

Kossmann, Political Thought in the Dutch

Republic: Three Studies (Amsterdam 2000); T.J.

Veen, Recht en Nut. Studiën over en naar aanleiding

van Ulrik Huber (1636-1694) (Zwolle 1976).
38

Cf. the contribution of Bas van Bavel in this volume. 
Such exceptionality inevitably drew much attention to the Dutch Republic, and never more so than in the crisis of 1672, when Europe's most powerful state seemed on the point of total collapse. Only one year later, Temple published his Observations upon the United Provinces of the Netherlands, one of the first books to be written by a foreigner in praise of Dutch society and politics; certainly one of the most perceptive and probably the most widely read and influential. ${ }^{39}$ Temple wanted lessons to be learned from his analysis of Dutch government and society by rulers of other countries. There can be no doubt that he idealized the United Provinces, but the image of the country he presented - the image of a free nation, well-governed and prosperous, an exemplary community, educated, tolerant and humane continued to be valued long after Temple composed it, precisely because it was an ideal and thus able to inspire rulers and policy-makers for centuries to come. $^{40}$

However influential the Dutch model might have been, much of Dutch radicalism and its moderate reaction were only fit for indigenous consumption as they originated in religious and political issues that were typical of the Republic. The transformation of the Dutch debates into more easily exportable ideas and concepts was the unexpected result of the wars and ensuing chaos Louis XIV's aspirations for a Monarchie Universelle had imposed on Europe since 1672. This put the Republic at the heart of a Europe-wide coalition against Louis XIV's imperial adventures, and made The Hague the centre of European diplomatic intelligence.

By the middle of the seventeenth century, the Dutch Republic was already one of the major centres of the European Respublica Litteraria, due to the fame of its universities, its religious tolerance and its international book trade, which flourished thanks to technological innovations, a highly developed credit system and an extensive shipping network. During the period 1670-1730, the Republic would become a world leader on the

William Temple, Observations upon the United

Provinces of the Netherlands, G. Clark (ed.)

(Oxford 1972), quotation at page 129. The

Observations ran through eight English editions between 1673 and 1747, besides appearing in

Dutch and French translations. Though Temple is rarely included in the Enlightenment canon, he was a political scientist and, anticipating Montesquieu, devoted attention to factors such as climate and physical geography. He wrote about religion in the Netherlands as 'a mere secular man' - in other words, not from any particular confessional standpoint. And he was later to publish an influential essay in comparative religion, ranging from the Islamic world to China and Peru: Temple, Miscellanea: The Second Part (London 169o) iii, 'Upon heroick virtue'. I thank Hugh Dunthorne for his valuable information on Temple.

40 For the role of the Dutch example: Hugh

Dunthorne, 'The Dutch Republic', in: M.

Fitzpatrick et al. (eds.), The Enlightenment World

(London 2004) 87-90 and Wijnand W. Mijnhardt,

'The Declaration of Independence and the Dutch Legacy', in: James Peltz (ed.), Opening Statements: Law and Jurisprudence in Dutch New York (Albany, forthcoming). 
intellectual market and it is this period that we should consider as the true Golden Age of Dutch intellectual history. The permanent state of war from 1672 until 1715 was responsible for waves of diplomats, spies and intellectual refugees flooding the towns of Holland in rapid succession. The expulsion of Huguenots from Catholic France since the 1670s brought some 50,000 refugees to the Republic but, even more importantly, this also transplanted the creative core of French intellectual life to the province of Holland. The 'Randstad', the urban band across the heart of Holland consisting of Amsterdam, The Hague, Leiden, Rotterdam and Utrecht, became the undisputed focus of the cosmopolitan Republic of Letters and the centre of an emerging European knowledge society. Intellectuals from all over Europe convened here for shorter or longer periods in informal societies and exchanged their views on public affairs which, due to Louis xIv's religious and absolutist policies, had obtained a new and pressing urgency. Assisted by the Dutch publishing industry, these literati also developed a new medium - the intellectual journal - that gave their ideas, books and quarrels a large and rapid, previously unimaginable circulation. ${ }^{41}$ Holland's preponderance was so overwhelming that, in 1700 , the Italian journalist Georgio Leti had to confess, in an analysis of the European political and economic system, that Holland alone completely dominated the world market for books and journals. ${ }^{42}$

It was in this cosmopolitan milieu that the Dutch urban Enlightenment found its European audience. Even though William of Orange presided, as a leader of the European coalition against Louis XIV and as a stadholder-king, over a transformation of politics which would turn England into a moderate monarchy supported by a temperate NewtonianAnglican establishment and the United Provinces into an aristocratic Republic with some democratic elements, leaning on an anti-Spinozist, NewtonianCalvinist clergy, the moderate twist seemed only to fuel religious and political debate. At the turn of the century, Huguenot refugees from absolutist France, frustrated courtiers from Italy, disillusioned intellectuals from the German lands and radical republicans from England, hosted by disenchanted theologians and political philosophers from the Dutch Republic, would continue to cherish the legacies of Descartes, Spinoza and the Dutch radicals of the 1660 s and the reaction to these.

Community in the Republic of Letters, 1680-1750

(New Haven 1995) 54-114; John Marshall, Locke and Early Enlightenment Culture (Cambridge 2007) 469-534.

[olland] alleen gansch Europa, met het werk der drukkerijen en boekhandel heeft bestraalt en verrijkt' in: Gregorio Leti, Kort begrip der helden-deugden, ofte Historische, en staat-kundige verhandeling van de daden en maximen, die tot voortplanting, en conservatie van alle staten, en landen noodsakelijk zijn... / in het Italiaans beschreven door ... Gregorio Leti ; en in de Nederlandse sprake overgebragt, door F. Hertogh (The Hague 1700) 17. 
The international audience readily accepted the ideas, vocabulary and languages of tolerance, democracy and criticism of religion used by Dutch literati, radical as well as moderate, in their interventions, but they transformed and applied these to their own problems. Information on these groups, their plans and their ideas is still limited, as research on them has only just begun. Even though Jonathan Israel in his Radical Enlightenment has charted important parts of this process, we need to know much more about contacts between the representatives of the various Enlightenment projects that were taking shape, about their activities in bookshops, in printing ventures, in informal circles, libraries and secret societies. A full revision of this founding phase of the European Enlightenment is utterly dependant upon a renewed analysis of the complicated adaptation, transformation and appropriation processes that accompanied the transfer of urban ideas over space and cultures. A reconstruction of the various forms of sociability in particular is indispensable in helping us conceive of the complicated relationships between ideas and political and cultural practices.

The basic pattern by which languages and ideas were transmitted is visible though, and I will present a few examples here. The type of tolerance, for instance, John Locke was to propose in his Letters on Toleration, shows a remarkable resemblance to the ideas circulating in circles of Dutch Arminians since the 1620 s. It is precisely in this milieu that Locke found his intellectual refuge in the 1680 s, and his Amsterdam friend Philippus van Limborch was instrumental in creating his ideas. ${ }^{43}$ The penetrating criticism of the Bible Richard Simon developed in his Histoire Critique du Vieux Testament is intellectually inconceivable without the influence of Grotius and the Dutch radicals, especially Spinoza and Lodewijk Meijer, and Simon would provide the basis for much Enlightenment thought on comparative religion. It is only logical that it was impossible to print the book in France in its entirety. ${ }^{44}$ In 1685 , the Rotterdam publisher Reinier Leers would put out the first complete edition, just as he did for that other basic compendium of early Enlightenment thought, Bayle's Dictionnaire. All subsequent reprints of this work also originated in the Dutch Republic. ${ }^{45}$

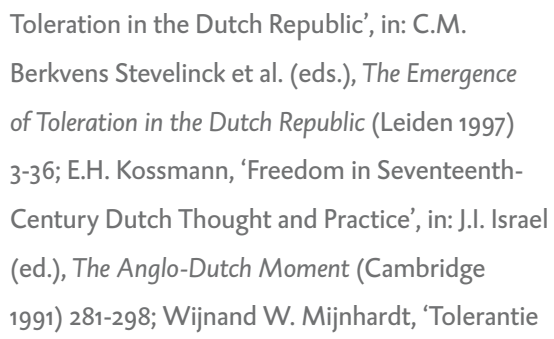

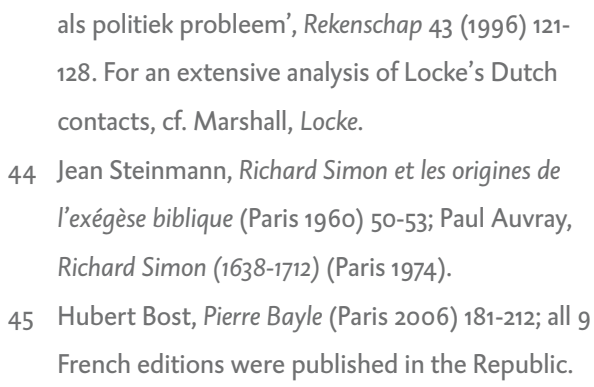


Equally instructive is the career of Bernard Mandeville, one of the early Enlightenment's most radical political and social critics. His Fable of the Bees; or Private Vices, Publick Benefits (London 1714) opposed the moderate Enlightenment view, as for instance propagated by the Earl of Shaftesbury, that men are sociable beings and naturally inclined towards virtue. According to Mandeville, humankind was naturally inclined to indulge in the passions and even reason, he claimed, was unable to lead men or women towards virtue. His Dutch background is essential to an understanding of Mandeville's thought. Mandeville was born in Rotterdam as Barent de Mandeville, educated at Leiden University, and was completely immersed in Dutch philosophical radicalism. He continued to draw upon Dutch literature and examples, even after moving to London, and tried to teach English politicians (just like John Toland, another English radical exiled in the Republic did), to 'govern all men by the spring of their own passions..${ }^{46}$ Mandeville's dependence on Dutch materialist and naturalist pornography is revealed by his Modest Defense of Publick Stews which defended prostitution on the same grounds as for instance ' $t$ Amsterdamsch Hoerdom, an infamous Dutch treatise on the subject.

Most Holland booksellers could hardly be expected to subscribe to everything they printed, but many adhered to the principle that anything that was fit to print and that was capable of finding an audience, ought to be made public to allow free and unrestricted discussion of the ideas it contained. In this context, we should interpret the 1719 publication of one of the most radical writings of the eighteenth century: La Vie et l'Esprit de Spinosa. The book consisted of two parts, which were barely connected. The first, La Vie de Spinosa, was probably written by the French journalist in exile Jean Maximilian Lucas (1646?-1692), who had ingratiated himself with the authorities as the author of one of the most vilifying hate campaigns against Louis XIV. La Vie de Spinosa contained the first biographical sketches of Spinoza and would become the chief source for Pierre Bayle's famous Spinoza article in the Dictionnaire.

The second, and most radical section, the Traité des Trois Imposteurs would be reprinted many times throughout the century. This treatise was hardly original, and consisted of a haphazard mixture of texts that had been circulating either in print or in manuscript form: Spinoza, Thomas Hobbes, and a few early seventeenth century libertines: Pierre Charron (1541-1603), 


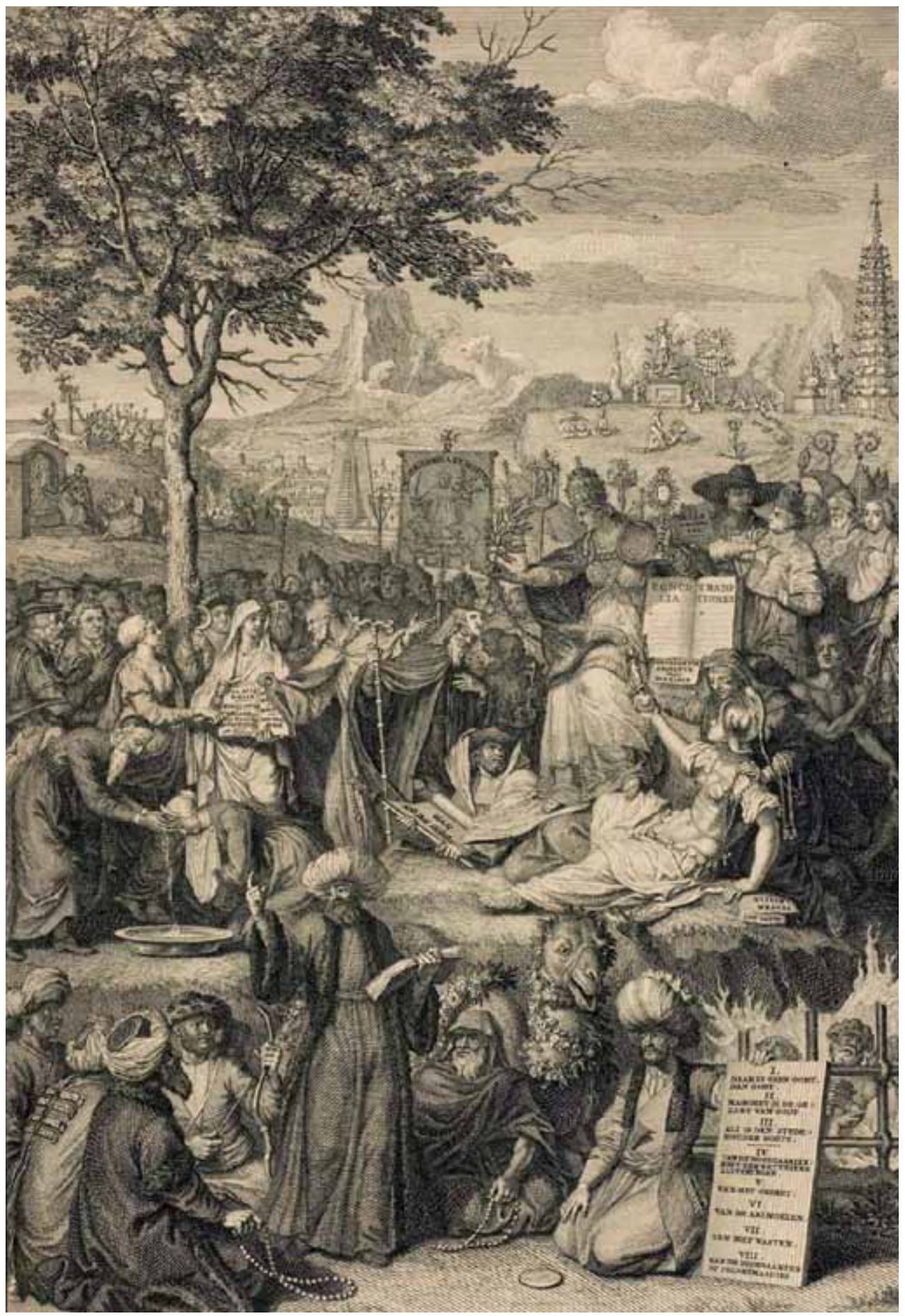

In Cérémonies et coutumes religieuses, Bernard and

Picart did something totally unique. They placed all the religions of the world as it was known at the time in a comparative perspective.
Title print of the Dutch edition of Cérémonies et coutumes religieuses.

Universiteitsbibliotheek, Utrecht. 
Lucilio Vanini (1585-1619) and Gabriel Naudé (1600-1653). The Traité stood out not because of its philosophical consistency, but because of its radical message: Moses, Mohammed and Jesus were simply three impostors who, by means of lies and deceit, had succeeded in making humanity believe in religions which, after all, were only the result of their personal imaginations. As a result, half a century before Voltaire's Dictionnaire Philosophique would tackle the issue, Dutch publishers had already launched a fundamental attack on religion, and on the Church and the State as its accomplices. ${ }^{47}$

A prominent figure in these circles of daredevil publishers was the Amsterdam bookseller of Huguenot origins, Jean Frederic Bernard; a good friend and colleague of Michael Böhm, Johann Fritsch, Prosper Marchand and Bernard Picart, who together were involved from the start in the publication of the Traité. The first book Bernard put on the market in 1711 was authored by himself and entitled Reflexions morales sur notre siècle. He denounced church and state equally as deceivers of the common people, but his methods were infinitely more sophisticated than those of the Traité. For Bernard, comparison was a key to the understanding of different cultures and religions. In his Réflexions morales, Bernard had included eleven letters from a Persian traveller, noting his observations of European politics, religion and society. The Réflexions served as the chief model for Montesquieu's Persian Letters a decade later; a best selling work that would become the model for comparing societies and cultures. ${ }^{48}$

During the period 1723-1737, together with the engraver Picart, Bernard would publish an impressive series in 7 folio volumes, comprising more than 3,000 pages and 250 large engravings, entitled Cérémonies et coutumes religieuses de tous les peuples du monde. His point of departure was the Cartesian principles of uniformity and regularity, which he thought to be applicable to social processes as well. This idea would guide his survey of all the religions of the known world. His grand catalogue of religious ceremonies would, in its somewhat understated fashion, help to sow the radical idea that religions could be compared. For the first time, even the so-called idolatrous peoples were treated on an equal basis: critically, but with respect. ${ }^{49}$

\footnotetext{
Imposteurs and Its Debt to Spinoza's Ethics',

in: Michael Hunter and David Wootton (eds.),

Atheism from the Reformation to the Enlightenment

(Oxford 1999) 181-220 and S. Berti, 'L'Esprit de

Spinoza: Ses origines et sa première édition dans

leur contexte spinozien', in: Silvia Berti et al.

(eds.), Heterodoxy, Spinozism and Free Thought

in Early-Eighteenth-Century Europe (Dordrecht,

Boston 1996) 3-52.
}

van Roosbroeck, Persian Letters before Montesquieu (New York 1932) 59-86.

49 Wijnand W. Mijnhardt, Religie, tolerantie en wetenschap in de vroegmoderne tijd (Utrecht 2008). For a full treatment of the Ceremonies, Lynn Hunt, Margaret C. Jacob and Wijnand Mijnhardt, The Book that Changed Europe: Picart and Bernard's Religious Ceremonies of the World (Cambridge Mass. 2010). 
The language of prejudice that had characterized similar surveys up to then was completely absent. He wrote about religion in new and sometimes irreverent ways. He held it up for examination, turned it over, and pried into its inner workings. Religion ceased being a given, defined by one's relationship to a God-given book that revealed absolute truths and a church that explained these. It became instead a set of beliefs and ritual practices that could be studied for insight into human nature in general. Jean Frederic Bernard and Bernard Picart saw themselves as the successors of the sixteenth-century Reformation. The Reformers initiated the process of removing superfluous ceremonies and superstitions; Picart's and Bernard's Ceremonies and Customs would continue that vast enterprise, aiming at a universal and natural religion that eventually would be put into words by Rousseau in his tale of the Savoyard Vicar in Emile: knowledge of God is found in the observation of the natural order and one's place in it; any organized religion that correctly identifies God as the creator and preaches virtue and morality is therefore true..$^{0}$

The French-speaking world in Holland, just like the English and the German, was well integrated into Dutch culture and society. Jean Frederic Bernard's grandfather, for example, was a Calvinist professor at the Protestant Collège d'Orange in the principality of Orange in the south of France. He was a good friend of Constantijn Huygens during his stewardship of the principality, as both men were great admirers of Petrarch and together, as the family tradition has it, they climbed Mont Ventoux. Bernard's father, who had been a Huguenot pastor in the small Provençal town of Velaux until the Revocation of the Edict of Nantes in 1685, had often married and baptized parents and children of the Dutch merchant community in Marseille. The Dutch consul there had been his great friend, and he would go on to witness Bernard's will in Amsterdam in 1694. Picart had married the daughter of a wealthy Dutch paper merchant in Amsterdam, IJsbrand Vincent, who was related to the famous Haarlem natural history collector, Levinus Vincent. IJsbrand was the president of Nil Volentibus Arduum, the radical society of which Lodewijk Meijer had been a prominent member. In the early eighteenth century, Nil still figured as a critical society and shared members with other liberal and libertine debating organizations, such as Benjamin Furly's Rotterdam Lantern, the Collegiants and the circle of the Deurhovians, the followers of Willem Deurhoff (whose portrait was etched by Bernard Picart). Vincent supplied paper to the printing business of Jean Frederic Bernard, and both were interested in French theatre and French literary culture..$^{51}$ All three distinction between Christian ethics and those of other religions: 'parmi tant de cultes inhumaines et bizarres (...) vous trouvez partout les mêmes idées de justice et d'honnêteté, partout les mêmes notions du bien et du mal', in: Oeuvres Complètes de J.J. Rousseau (Paris 1959-1995) volume IV, 597 ff. 
men, Picart, Vincent and Bernard, shared memories of suffering under a cruel religious regime; they shared experiences as exiles in a foreign land, and their wide-ranging debates in inquisitive religious circles had convinced them that the Dutch Republic, despite its many defects, was the best possible society on earth. Bernard's Reflexions Morales frequently testified to this. The Republic was the only state in which the rule of law was taken seriously. ${ }^{52}$

Dutch intellectual culture served both worlds: a Dutch intellectual community of Enlightened persuasions, and a cosmopolitan one. Together, they built the foundations of early Enlightenment thought, both moderate and radical.

\section{The closing of the Dutch mind}

Dutch supremacy on the intellectual world market was not destined to last. Jean Frederic Bernard, for instance, began his career at its climax, in 1711, but by his death in 1744 the Dutch Republic had lost its preponderant position. The relative peace in Europe after 1715 and the growth of tolerance elsewhere meant the Republic served less often as a refuge for intellectuals and publishers. England now became an important intellectual centre, and in France the new intellectual elite exemplified by Montesquieu and Voltaire still saw the Republic as an essential European print shop, although it no longer needed it as a place of exile. ${ }^{53}$ Even Germany - which for a very long time had served as a student reservoir for Dutch universities - now came into its own. Soon, even the German states would become exporters of professors, instead of importers. ${ }^{54}$ After 1750 , the position of the Republic as a European clearinghouse for French books and journals began to suffer. Mostly as a result of the same sort of structural changes that affected the Republic's economy as a whole: the emergence of cheaper and much more conveniently located book production centres elsewhere, notably in Bouillon and Neuchâtel. In the second half of the century, the Dutch book trade only succeeded in maintaining its international repute as a production centre of classical and oriental scholarship. 55

Wijnand W. Mijnhardt, 'Jean Frederic Bernard

as Author and Publisher' and Inger Leemans,

'Picart's Dutch Connections: Family Trouble,

the Amsterdam Theater and the Business of

Engraving', both in: Lynn Hunt, Margaret Jacob

and Wijnand Mijnhardt (eds.), Bernard Picart and

the First Global Vision of Religion (Los Angeles

2010).

52 J.F. Bernard, Reflexions Morales et Satiriques \&

Comiques sur notre Siècle (Cologne 1711) 263.
53 Roy Porter, The Creation of the Modern World (New York 2000) 72-95.

54 H. Schneppen, Niederländische Universitäten und Deutsches Geistesleben (Munich 1960); Joke Roelevink, Gedicteerd Verleden (Amsterdam, Utrecht 1986) 7-32.

55 I.H. van Eeghen, De Amsterdamse boekhandel 1680-1725, volume V (2 parts; Amsterdam 1978): 'De boekhandel van de Republiek'. 
The background to the Dutch retreat from the international intellectual scene was much more complicated, however. First of all, Dutch intellectuals had much trouble interpreting Dutch de-urbanization and the economic decline that accompanied this. Though some Amsterdam merchants knew from the very beginning that the Dutch miracle resulted as much from contingent factors as from genius, to most the process of economic and urban decline remained difficult to explain. The consequences were immense, however. As demand for workers continued to fall, immigration came to a virtual standstill. While in the seventeenth century, immigrants made up about 8 percent of the Dutch population, albeit with heavy concentrations in the Holland towns, where foreigners could account for $30-40$ percent of the population, by the eighteenth century most cities not only became much smaller and more self-centred, they also became much more homogeneous. Whereas in the seventeenth century urbanization had made it almost impossible to implement religious and political uniformity, creating a thriving and innovative culture that laid the foundations for pioneering Enlightenment thought, in the eighteenth century, urban economic decline produced uniformity and cultural homogeneity, preparing the ground for an inward-looking, moderate version of Enlightenment thought that would slowly become the intellectual standard of the Dutch Republic. Central to this process were the radically changing attitudes towards French intellectual culture.

Struggling to find explanations for the decline of the western seaboard towns, Dutch literati experienced greater difficulties adapting to the Frenchlanguage-oriented République des Lettres on Dutch soil of the early eighteenth century than to the Latin-based Respublica Litteraria of the middle of the seventeenth. The battle against a French Monarchie Universelle which kept the Republic in a costly war for almost half a century, together with the presence of an active French-language press within its borders, forced a division in the Dutch intellectual community. Many literati enjoyed participating in the cosmopolitan world of the Republic of Letters, but a growing band of Dutch poets and professors saw the French press as a Trojan horse that only could mean the first stage of French cultural - and ultimately political dominance. ${ }^{56}$ By the end of the seventeenth century already, in a formal lecture at the Atheneaum Illustre, the Amsterdam professor Petrus Francius came to the conclusion that French cultural imperialism was the harbinger of political subjection: 'tamquam praecursorem Imperii sui'. ${ }^{57}$ And the most

an extensive analysis of these two cultures on Dutch soil, see W.W. Mijnhardt, 'Dutch Culture in the Age of William \& Mary: Cosmopolitan or Provincial', in: D. Hoak and M. Feingold (eds.),
The World of William \& Mary: Anglo-Dutch Perspectives on the Dutch Revolution of 1688-1689 (Stanford 1996) 219-233.

57 Petrus Francius, Orationes in Unum Collectae (Amsterdam 1692) 108. 
famous neo-Latin poet of his generation, Jan van Broekhuizen, who served in the Dutch armies resisting the French, claimed in various poems and letters to his friends that French culture exercised a nefarious influence on Dutch virtues, and therefore on the ability to overcome the French 'monster. ${ }^{58}$

When the Peace of Utrecht failed to produce the fruits that were expected, and economic decline and a loss of international respect slowly began to make themselves felt in all domains, some literati even began to discuss the lamentable state of the Republic in their poetry, comparing it to a lame duck. ${ }^{59}$ In this context, a new dimension was added to the traditional anti-French debate. As Dutch economic and political prosperity were perceived as closely connected to Dutch cultural and moral superiority, the already familiar anti-French currents were now transformed into an explanatory ideology for the problem of international decline. Whereas, up to now, the French-language press and its Dutch literary partisans had been held responsible for disseminating French culture, now the regents - increasingly blamed for the economic and international setbacks - began to be criticized for having adopted the very French cultural modes patriotic Dutch literati had been rebelling against.

This fundamental shift in anti-French feeling and the definitive turn towards an anti-cosmopolitan and more inward-looking mentality gained currency in the Hollandsche Spectator (1731-1735), a very influential journal which served as a model for a host of similar Dutch periodicals in the decades to come. ${ }^{60}$ Its author was Justus van Effen, a journalist who had begun his career in the French cosmopolitan world of publishing journals, such as the Journal Litéraire. The reasons for Van Effen's conversion are not quite clear. ${ }^{61}$ It seems, however, that he also had become affected by the growing international contempt for the Republic. His Hollandsche Spectator served as the interpreter of recent feelings of anxiety about the future of the Republic. It absorbed the national cultural ideology and tried to find an explanation for the symptoms of decline. Perceiving the causes of decline as moral, the Spectator indicted the regents' imitation of French manners as moral degeneration. Only if the regents were prepared to abandon their French and aristocratic

58 A. Worp (ed.), Epistolae Selectae aliarumque Epitomae et Fragmenta (Jani Broukhusii) (Groningen 1889) 110, 112, 113-116, 123, 124. For Broekhuizen's anti-French poems, see D. van Hoogstraten (ed.), Jani Broukhusii Poemata libri sedecim (Amsterdam 1711) 166-168.

59 'Klaght over den tegewoordigen toestant des Vaderlants' (1717), in: J. de Haes, Gedichten (Rotterdam 1720) 447-450.

60 De Hollandsche Spectator (Amsterdam 1731-1735)
See the essays by P.J. Buijnsters on the Dutch spectatorial genre in: P.J. Buijnsters, Spectatoriale Geschriften (Utrecht 1984).

61 For an interpretation of Van Effen's conversion to the Dutch cause, see Wijnand W. Mijnhardt, 'The Dutch Enlightenment: Humanism, Nationalism and Decline', The Dutch Republic in the Eighteenth Century: Decline, Enlightenment and Revolution, Margaret C. Jacob and Wijnand W. Mijnhardt (eds.) (Ithaca, London 1992) 197-224. 
cosmopolitanism and return to a national Dutch republican morality, would the Republic be restored to its former prosperity and prestige.

The fear of being overwhelmed by French political and cultural imperialism alike produced a vigorous search for a distinctive national cultural identity. In the course of this process, Dutch intellectuals came to consider language and literature of a humanist persuasion as the cornerstones of national consciousness and as the touchstones of republican virtue. ${ }^{62}$ As a result, instead of losing its unique national character, Dutch culture in this period became distinctly more national - even provincial - to the extent of losing its former central position in European cosmopolitan culture.

The intimate connection between Dutch cultural nationalism and contemporary perceptions of deepening economic and political decline was responsible for a strong retrospective inclination. This retrospective cultural nationalism would seriously influence the character of the Dutch Enlightenment. It consisted of a peculiar mixture of visions of decline, religion and Enlightenment, as developed by Dutch intellectuals. They began to interpret Dutch society as a moral community in which religion, patriotism and good citizenship were expected to enhance one another. Together, these would enable citizens to overcome the country's decline and to restore the nation to its former glory. Eventually this new version of Dutch urban Enlightenment thought would serve as an essential prerequisite for its own peculiar twist in the 1780 and 1790 : but that is another story. ${ }^{63}$

Only in the 1770s, and stimulated by the development of enlightened aesthetics, did art and its seventeenth-century legacy come to be included in the concept of a national Dutch culture. Cf. P. Knolle, ‘Cornelis Ploos van Amstel, pleitbezorger van een 'Hollandse' iconografie', Oud-Holland 98 (1984) 46-47; E. Koolhaas-

Grosfeld, 'Nationale versus goede smaak.

Bevordering van nationale kunst in Nederland 1780-1840', Tijdschrift voor Geschiedenis 95 (1982) $605-636$.
63 For a survey of the development of Dutch cultural nationalism in the eighteenth century, Wijnand W. Mijnhardt, 'Natievorming in het revolutietijdvak', BMGN 104:4 (1989) 547-553 and N.C.F. van Sas, 'Vaderlandsliefde, nationalisme en vaderlands gevoel in Nederland, 1770-1813', Tijdschrift voor Geschiedenis 102 (1989) 473-476. For an extensive treatment of Dutch eighteenthcentury Enlightenment thought, see Kloek and Mijnhardt, 1800: Blueprints for a National Community (footnote 8). 
Wijnand W. Mijnhardt (1950) is a Professor of Comparative History of Science and Director of the Descartes Centre for the History and Philosophy of the Sciences and the Humanities (Utrecht University). He has published on scientific infrastructure and on the European Enlightenment, including (with Margaret Jacob and Lynn Hunt), The Book that Changed Europe: Picart \& Bernard's Religious Ceremonies of the World (Cambridge Mass. 2010) and (with J.J.Kloek), 1800: Blueprints for Dutch Society (London 2004). This article is a preliminary study for: 'An Urban Enlightenment: The Dutch Republic 1640-1815', which is nearing completion. 


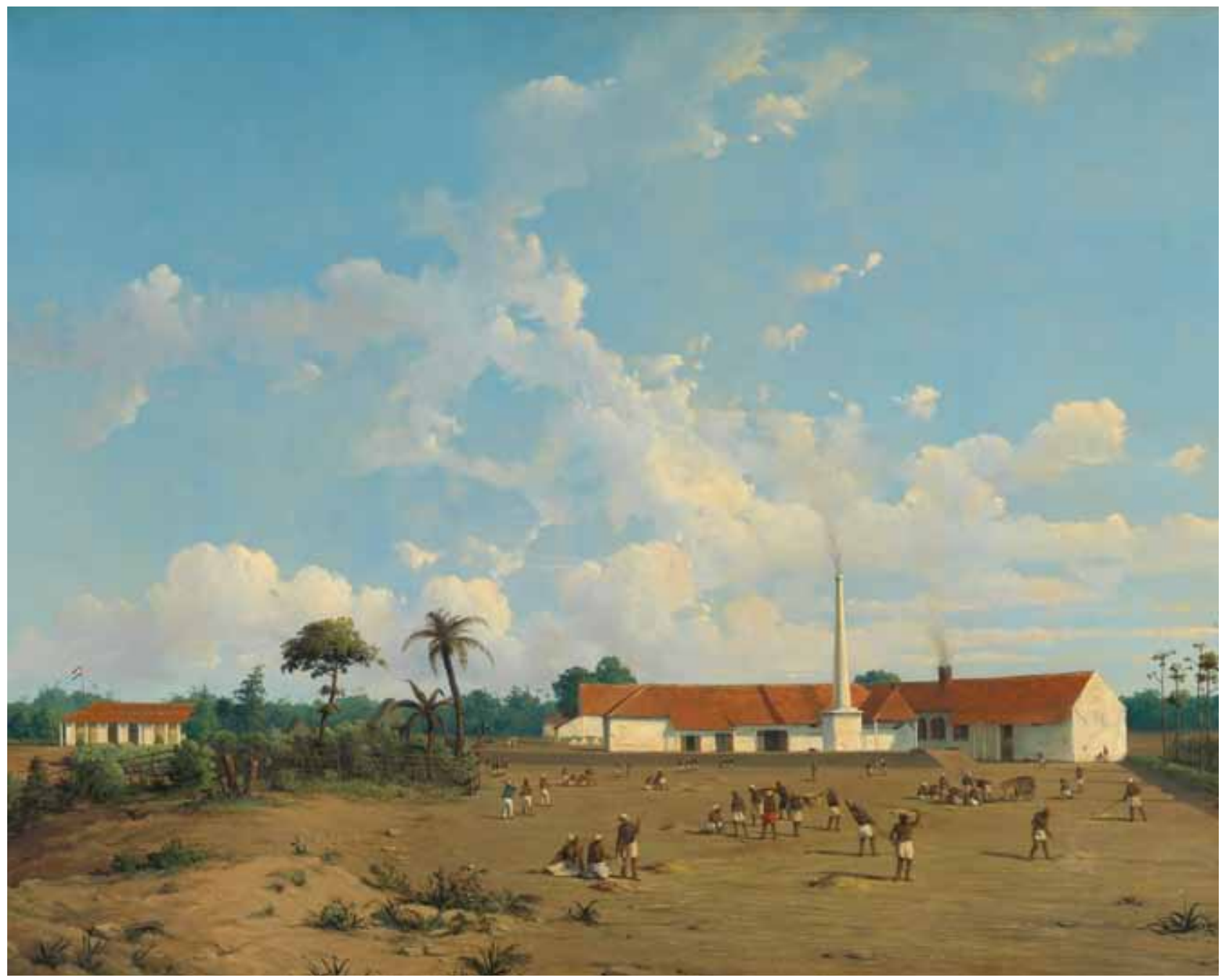

The 'Kemanglen' sugar factory at Tegal (or Tagal) on Java, founded in 1841 by Th. Lucassen. View of several white buildings (sugar factory) with a smoking factory chimney. On the left a house with the Dutch flag in front of it (administrator's house). In front of the factory, groups of natives are working with the sugarcane. Far right, lane with (kapok) trees.

Ab Salm, The 'Kemanglen' sugar factory at Tegal (or Tagal) on Java, around 1870-1875.

Rijksmuseum, Amsterdam. 


\title{
The Dutch Empire. An Essential
}

\section{Part of World History}

\author{
WIM VAN DEN DOEL | LEIDEN UNIVERSITY
}

In this article, a number of aspects of the history of Dutch colonialism are linked to developments in world history. A number of themes are covered by this approach, such as the consequences of the worldwide revolutions around 1800 , the Cultivation System, modern imperialism, the rise of the colonial state, nationalism and decolonisation. The aim is to show that the development of specific parts of the world was linked to major, worldwide historical processes through links that arose thanks to Dutch colonialism. I further argue that knowledge of the history of Dutch colonialism is essential to an understanding of these major, worldwide processes.

When the Netherlands was still a colonial power nobody needed to be convinced of the necessity to study the Dutch example. After what the British called the Indian Mutiny, a Calcutta-based English lawyer, J.W.B. Money, wrote his famous Java: Or How to Manage a Colony. Showing a Practical Solution of the Questions Now Affecting British India. In the book, Money concluded that India, if

\footnotetext{
raised to the same condition as Java, would form the grandest empire it has ever yet entered into the heart of man to conceive. Without annexing another mile of Native territory, the same population per square mile, and the same revenue per head, would give us upwards of 170 millions of people, yielding a revenue of more than 130 millions of pounds sterling per annum, not only without impoverishing themselves, but while daily increasing in wealth, in contentment, and in civilization. ${ }^{1}$
}

After Money, other writers looked at what was happening in the Dutch colonial empire: from the colonial civil servant John S. Furnivall, who published his famous Netherlands India: A Study of Plural Economy in 1939, to the French scholar H.H. Bousquet, who in the same year published La politique Musulmane et colonial des Pays-Bas. American observers were more critical, as can be seen in Rupert Emerson's, Malaysia: A Study in Direct and Indirect Rule (1937). 